\title{
Perceiving Auditory Stimuli: Inter-Species Adaptation Differences, Harmonics, and Illusions
}

\author{
Lucas Roitman*, Poppy Crum \\ Stanford Center for Computer Research in Music and Acoustics, Stanford university, USA
}

Submission: May 28, 2018; Published: July 09, 2018

*Corresponding author: Lucas Roitman, Honors Thesis in Science, Technology and Society, Stanford's Center for Computer Research in Music and Acoustics, California, USA, Email: roitman@alumni.stanford.edu

\begin{abstract}
Illusions give us insights regarding how physiological systems use and weigh information fromdifferent inputs. Physiological systems interpret data in in such a way that we can understand allof it as a whole concept. We will discuss and understand these processes, as well as thetechnical processes that convert stimuli to electrical impulses in the human auditory system. Wewill propose experiments, explain evolutionary adaptations to improved hearing in other species,explain harmonics and Weber's law relating perception and stimuli[1].
\end{abstract}

Keywords: Illusions; Physiological systems; Visual inputs; Evolution; Environment; Potential predators; Vibrations; Specific frequencies

\section{Cognitive Improvements}

Illusions give us insights regarding how physiological systems use and weigh information fromdifferent inputs. Physiological systems interpret data in in such a way that we can understand allof it as a whole concept.

In some cases, that leads to our brain creating illusions by applying the wrong conceptualgrouping, for example, to the available stimuli[2]. Physiological systems assign more weight tovisual inputs, for example, and the brain groups auditory or visual stimuli based on location andsimilarity to create a virtual model of the perceived world. Attention changes depending on thesituation, as our interpretation of stimuli has developed via evolution.

Illusions can be very artificial and controlled by humans, but some are also common in naturalsettings. An example is that many animal species can camouflage themselves in theirenvironment, giving the illusions to potential predators or preys that the animal is part of thebackground or environment. Some species such as the chameleon can also change the color oftheir skin to adapt to different environments.

\section{The Process of Hearing}

When a pressure wave reaches the ear, it transforms to an electrical signal, which leaves theauditory nerve for higher neural levels. First, the pressure wave enters the outer ear, composed of the auditory canal and the pinna, then goes through the meatus, causing tympanic membranevibrations. The eardrum then transmits the vibrations to the cochlea via the ossicles, which aresmall bones in the middle ear[3].

The ossicles in the middle ear are used to decrease reflections caused by a difference inimpedance. The cochlea, which is in the inner ear and is shaped as a spiral filled with a fluid,goes from the base to the apex (the tip), has two membranes (the basilar membrane andReisner's membrane). At the base, there is the oval window, and at the apex, there is anopening between the walls of the cochlea and the basilar membrane, connecting the outerchambers of the cochlea (scala tympani and scala vestibuli).

The physical vibrations wave reaches the basilar membrane, which Von Bekesy discovered thatvibrates and transfers the wave to the apex. As the fluid moves through the endolymph andperilymph, the waves stimulate the receptor cells that send nerve impulses to the brain. In theorgan of Corti, the four rows of hair cells between the tectorial membrane and the basilarmembrane are depolarized by the basilar membrane.

The inner hair cells transform fluid vibrations into electrical signals that are sent through theauditory nerve to the auditory brainstem and the auditory cortex, while outer hair cells are usedto amplify soft sounds in the cochlea. Their electromotility is an amplifier that mechanicallyincreases hearing sensitivity in specific frequencies that are important to hear.

The hair cells release neurotransmitters at synapses with the auditory nerve fibers, creatingaction potentials, which 
convert the vibrations in the basilar membrane to firing patternstransmitted to the brainstem.

\section{Experiment}

It is possible to measure a critical band by masking a sine wave with a white noise band. Bydecreasing the bandwidth of the white noise until the sinewave is identified, the band widthreaches the critical bandwidth. Hereis a graph showing the hypotheticaloutput of this test.By adding another noise band at adifferent critical band, as long as it ismodulated in the same way as thefirst noise band, the brain wouldidentify the pattern and be able toseparate them from the sine wavewhich is not modulated in the sameway. This could further lower thethreshold(Figure 1).

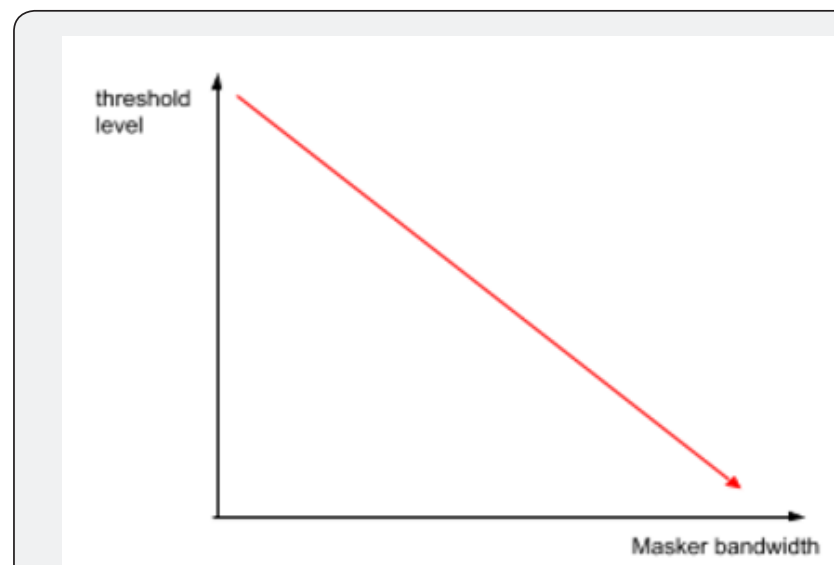

Figure 1: Masking graph.

There are multiple types of masking: Simultaneous masking, when a sound is maskedby another sound that is played during the entirety of the first sound. Non-simultaneousmasking is when a sound cannot be interpreted by the human brain because another soundhas been played very soon before or after, and it causes the illusion of having been part of thesame group and is therefore masked[4].

\section{Evolutionary Adaptations}

There are species with evolutionary adaptations that have enabled them to hear in remarkablyunique ways. Dogs have evolved in such a way that they can move their ears in differentdirections to capture and amplify sounds from those directions[5]. Some owls cannot move theireyes, which means they can more easily map vision to hearing, and thus have a stronger spatialconnection between vision and audition[6].

Bats have evolved to the point of being able to echolocate their preys and environment[7]. Somehumans are also able to achieve this. Some insects have also learned to hear these sounds thatbats emit. For example, some butterflies can sense these vibrations in their wings, which makethem drop to the ground and avoid being captured[8].

\section{Harmonics}

The perception of a $100 \mathrm{~Hz}$ Sawtooth wave, if all the odd harmonics are removed, will remain asawtooth wave but in the next harmonic $(200 \mathrm{~Hz})$, because all the even harmonics for $100 \mathrm{~Hz}$ areALL of the harmonics for the $200 \mathrm{~Hz}$ wave.Therefore, it will be exactly an octave higher.

In order to create the 60 phon curve, for exampleone would have to play a $60 \mathrm{~dB}$ tone at $1 \mathrm{kHz}$, andthen play tones at other frequencies and measurewhich volume intensity in $\mathrm{dB}$ would perceptuallymatch the $1 \mathrm{kHz} 60 \mathrm{~dB}$ initial tone. Thus, the curve will always provide 60phons at anyfrequency (Figure 2). The A level weighting was made for under 40 phons, so a regular classroom wouldneed to be measured with an A-level meter. For a rock concert, $\mathrm{C}$-level would be moreappropriate since it was designed for louder sound, around 100phons.

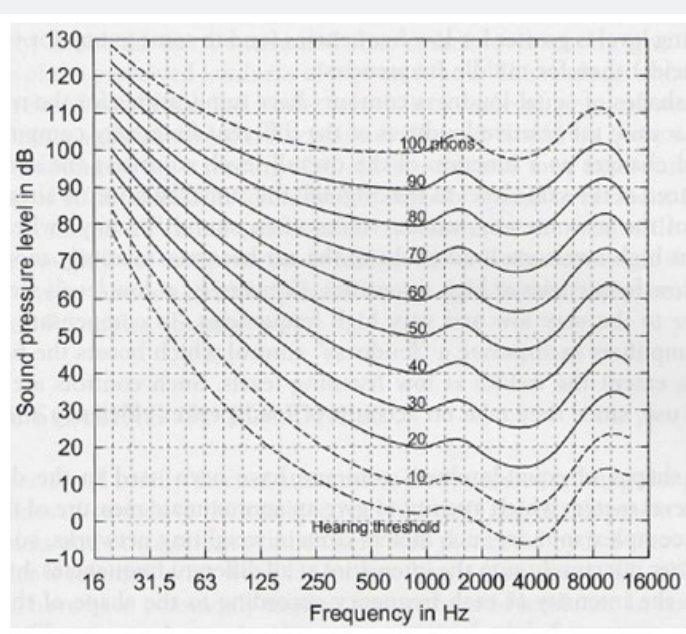

Figure 2: Harmonics.

\section{Near Miss to Weber's Law}

The Near Miss to Weber's law is when at high frequencies, the law doesn't apply anymore[9]. Itprobably occurs because at high frequencies, loudness perception differences converge. This islikely to be an effect of the nonlinear scale of sound perception. For example, there is a higherfrequency separation between $\mathrm{C} 3$ and $\mathrm{C} 4$ than $\mathrm{C} 4$ and $\mathrm{C} 5$, and that could create a smallerdifference in perceived volume difference, according to Steven's Power $\operatorname{Law}[10]$.

\section{Conclusion}

In conclusion, illusions can help shed light on the systems and mechanisms that our brain usesto understand the environment, by combining multiple auditory and visual clues into a coherentrepresentation of the world.

We analyzed some of these systems and gave examples on how the ear mechanism works, with the cochlea, going from the base to the apex, hair cells and auditory nerve fibers. Finally,we proposed future experiments to measure critical bandwidth for masking of auditory cues.

\section{See Other Papers by This Author:}

1. Roitman Lucas Agudiez, Alex T, Sebastian T (2014) Real-time visual subject tracking and classification by 
combining motion signal analysis and tridimensional-shape feature classifiers with group-induction boosting algorithms. SURJ: The Stanford Undergraduate Research Journal.

2. Roitman Lucas Agudiez, Kyoko S, Terry W, Kevin Di P, Jeff (2016) A comparative analysis of Augmented Reality technologies and their marketability in the consumer electronics segment, Honors Thesis in Science, Technology and Society: Innovation and Organizations, Stanford University. Journal of Biosensors \& Bioelectronics.

3. Roitman Lucas Agudiez, Zhang Y, Tan Z, Canfei He (2014) Social Stratification and Residential Segregation in Haidian District, Beijing, China. International Journal of Economics \& Management Sciences.

4. Roitman Lucas Agudiez, Eric Roberts (2013) The impact and tradeoffs of technology, communism and inequality in the fiction of Brave New World. Grin Verlag.

5. Roitman Lucas Agudiez, Daniel F, Julie T (2017) Playing God: Eradicating Malaria and Mosquitoes in the Developing World with Gene Drives and CRISPR/Cas9. Journal of Nanomedicine and Nanoscience Research.

6. Roitman Lucas Agudiez, Anusha B, Tum C, Frank F, Haque I, Johnny I, Anshul K (2016) Smarter initializations in multi-modal neural networks to predict transcription factor binding.

7. Roitman Lucas Agudiez, Michael S (2014) The new Industrial Revolution: manufacturing with 3D Printers and Polymer Materials in an Economy of Design, Innovation and Intellectual Property. International Journal of Economics \& Management Sciences.

8. Roitman Lucas Agudiez, Mark V (2014) Copyright Enforcement and Piracy Controls as an Excuse for Corporate and Political Domination. Grin Verlag.

9. Roitman Lucas Agudiez, Kenneth S, Kerry P (2014) Analyzing internal political factors that impact foreign intervention decisions by the United States government.

10. Roitman Lucas Agudiez, Anshan Li, Suolao W (2014) Chinese intervention in the Middle East: How could it shift the balance of power? Grin Verlag.

11. Roitman Lucas Agudiez, Kenneth S, Kerry P (2014) U.S. Intervention in Syria Intervention Will Take Place in the Middle East during the Obama Administration. Global Journal of Human-Social Science: Interdisciplinary.

12. Roitman Lucas Agudiez, Michael M, Tomoki Eto, Banny B (2013) The Social Seat, an Urban Installation in the Age of the Internet of Things
13. Roitman Lucas Agudiez, Zhang Y, Tan Z, Canfei He (2014) Social Stratification and Residential Segregation in the Urban Fringe: A case study of the Haidian District in Beijing. International Journal of Economics \& Management Sciences.

14. Roitman Lucas Agudiez (2014) Diaspora, the decentralized social network as a technological utopian libertarian ideal.

15. Roitman Lucas Agudiez (2014) An analysis of Sony Corporation's horizontal and vertical integration in the Consumer Electronics market.

16. Roitman Lucas Agudiez, Canfei He (2014) The Economic and Organizational mechanisms for the Regulation of Urbanization in modern day China.

17. Roitman Lucas Agudiez, Poppy C (2014) Neuroplasticity and the use of visual and auditory illusions for improving musical and gaming abilities.

18. Roitman Lucas Agudiez, Marcelo C (2014) An introduction to Microeconomic Principles and their applications in multiple fields.

19. Roitman Lucas Agudiez, Jelena B, Eric R (2013) A social and ethical analysis of Thomas More's Utopia.

20. Roitman Lucas Agudiez, Michael S (2014) The Management and Organizational role of Scribes as Bureaucrats in Ancient Egypt.

\section{References}

1. Donald L (2008) Weber's Law.

2. Lupyan G (2008) The conceptual grouping effect: Categories matter (and named categories matter more) Cognition 108: 566-577.

3. Wartzok D, Darlene RK (1999) Marine mammal sensory systems. Biology of marine mammal's pp 117-175.

4. Hartley DEH, Beverlr AW, Sarah CH, David RM (2000) Age-related improvements in auditory backward and simultaneous masking in 6-to 10-year-old children. Journal of Speech, Language, and Hearing Research 43: 1402-1415.

5. Coppinger R, Lorna C (2001) Dogs: A startling new understanding of canine origin, behavior \& evolution. Simon and Schuster.

6. Schaeffel F, Hermann W (1992) Barn owls have symmetrical accommodation in both eyes, but independent pupillary responses to light. Vision research 32(6): 1149-1155.

7. Mogdans J, Hans-Ulrich S (1990) Range resolution and the possible use of spectral information in the echolocating bat, Eptesicus fuscus. The Journal of the Acoustical Society of America 88(2).

8. Zwislocki JJ (2009) Stevens' Power Law. Sensory Neuroscience: Four Laws of Psychophysics: 1-80.

9. Tate M (2013) Principles of hearing aid audiology. Springer.

10. Yack JE, James HF (2000) Ultrasonic hearing in nocturnal butterflies. Nature 403: 265-266. 


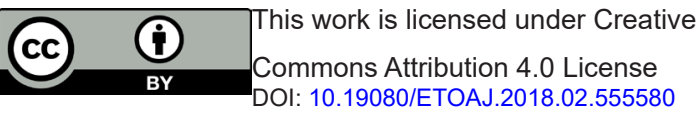

Your next submission with Juniper Publishers
will reach you the below assets
- Quality Editorial service
- Swift Peer Review
- Reprints availability
- E-prints Service
- Manuscript Podcast for convenient understanding
- Global attainment for your research
- Manuscript accessibility in different formats
( Pdf, E-pub, Full Text, Audio)
- Unceasing customer service
Track the below URL for one-step submission
https://juniperpublishers.com/online-submission.php

